American Journal of Agricultural and Biological Science 1 (2): 27-35, 2006

ISSN 1557-4989

(C) 2006 Science Publications

\title{
Study of the Mandibular Glands of Ant Workers Atta sexdens rubropilosa (Forel, 1908) (Hymenoptera: Formicidae) Focusing the Ultrastructural Cytochemistry
}

\author{
${ }^{1}$ Lorena Favaro Pavon and ${ }^{2}$ Maria Izabel Camargo Mathias \\ ${ }^{1,2}$ Universidade Estadual Paulista-Instituto de Biociências, Departamento de Biologia-Laboratório de \\ Microscopia Eletrônica, AV. 24-A, nº. 1515-Rio Claro-SP, Brasil-CEP: 13506-900-CP: 0199
}

\begin{abstract}
The mandibular glands of hymenopterans in general are paired structures located on each side of the head. These glands possess an excretory duct located at the internal surface of the mandible articulation, through which these glands release the secretion they produce. The mandibular glands of the minima, media and soldier worker of the ant Atta sexdens rubropilosa were analyzed by the methods of ultrastructural cytochemistry to verify the composition of the produced secretions. The results evidenced the presence of proteins, carbohydrates and lipids in the different portions of the mandibular glands. The cytochemistry also showed that the lipids present in the mandibular gland of the individuals of three worker castes would have at least two different sources: the smooth endoplasmic reticulum as well as the mitochondria present in the secretory cells cytoplasm. The present study showed that the mandibular glands of the individuals of the three worker castes of $A . s$. rubropilosa mainly the soldiers and media workers, who are individuals that perform tasks outside the nests and are thus more exposed to predation and/or infection and also the minima workers, who take care of the fungal culture, produce compounds that could play roles in alarm and/or defense.
\end{abstract}

Key words: Insects, glands, pheromones, secretion, transmission electron microscopy

\section{INTRODUCTION}

The mandibular glands of hymenopterans in general are paired structures located on each side of the head. These glands possess an excretory duct located at the internal surface of the mandible articulation, through which these glands release the secretion they produce.

The mandibular glands are part of the salivary system of insects, together with the salivary glands of the thorax, the post-pharyngeal glands and the hypopharyngeal ones. The glands that compose the salivary system secrete important substances for the process of social regulation of the insects colony, particularly regarding the different roles performed by the castes. The study of the roles performed by the multiple exocrine glands in social insects is of the utmost importance, given that several biological processes, such as feeding, female attraction, mating, communication, among others, depend directly on the products released by specific glands ${ }^{[1]}$. Among the glands of the salivary system, the mandibular glands are the ones that have strayed farther away from the role of feeding ${ }^{[2]}$.

Histological studies in queens of Apis mellifera ${ }^{[3]}$ observed that the glands of virgin queens presented a full reservoir while this reservoir was almost empty in mated queens, thus concluding that the secretion of the mandibular gland plays a role in sexual attraction during the mating flight.
Ultrastructural studies in ant workers of Atta sexdens rubropilos $a^{[4]}$ revealed the presence of three cellular types in the mandibular glands of these individuals: secretory cells, cells of the reservoir and extracellular canaliculi-forming cells. Among the cell types mentioned, the ones surrounding the reservoir and the ones forming the canaliculi appeared to be involved in the synthesis of the cuticle that coats the lumen of the canaliculi and the reservoir wall. The same study also revealed that two different cellular types produce the intra-and extra-cytoplasmic portions of the canaliculi. The secretory cell itself produces the intracellular portion while the extracellular portion is produced by special cells known as canaliculi-forming cells ${ }^{[5]}$.

Histochemical studies of the mandibular glands of worker ants of $A$. S. rubropilosa ${ }^{[6]}$ evidenced the existence of acid lipids, acid and neutral polysaccharides and proteins at the different parts of the gland. The authors concluded that the secretion produced by the mandibular glands of this species was lipoproteic in nature, thus strengthening the hypothesis that suggests a main role of alarm pheromone to the secretion it produces.

Therefore, the present study had the objectives of confirming through transmission electron microscopy what kind of element is produced by each mandibular gland cell or cell part of different castes of ants $A$. $s$. rubropilosa, as well as analysing the stored secretion in the reservoir. These analyses were carried out by

Corresponding Author: Maria Izabel Camargo Mathias, Universidade Estadual Paulista-Instituto de Biociências, Departamento de Biologia-Laboratório de Microscopia Eletrônica, AV. 24-A, nº 1515-Rio Claro-SP, Brasil-CEP: 13506-900-CP: 0199, Tel/Fax: 055-19-3524-0009 
employing the techniques of ultrastructural cytochemistry for the detection of proteins, lipids and carbohydrates.

\section{MATERIALS AND METHODS}

For the present study, minima, media and soldier worker of the ant Atta sexdens rubropilosa were collected from artificial nests kept in the laboratories of the Center for the Study of Social Insects-Centro de Estudo de Insetos Sociais (CEIS)-at the UNESP, campus at Rio Claro, SP, Brazil.

\section{Ultrastructural Cytochemistry}

Detection of basic proteins: The mandibular glands were fixed in $2.5 \%$ glutaraldehyde, washed in distilled water, incubated in ammonium silver solution $(10 \%$ silver nitrate added to a concentrated solution of ammonium hydroxide), according to the method of ammonium silver ${ }^{[7]}$, for $5 \mathrm{~min}$ at room temperature. Next, the material was washed in distilled water and incubated in 3\% formaldehyde for $5 \mathrm{~min}$, in which the material acquired a brown coloration. Immediately afterwards, the material was washed in distilled water and post-fixed according to routine procedures.

Detection of total sugars: The material was prepared following the routine for transmission electron microscopy (TEM). Once sectioned using an ultramicrotome, the ultrathin sections of the material were placed on gold meshes, letting the sections float on $1 \%$ periodic acid for 15 to $20 \mathrm{~min}$. This treatment was followed by successive baths in acetic acid at the following concentrations: $10 \%, 5 \%$ and $2 \%$, for $10 \mathrm{~min}$ each. After three 10-minute washes in distilled water, the meshes with the material were transferred to a solution of $1 \%$ silver proteinate for $30 \mathrm{~min}$ at room temperature and in the dark. Finally, the material was washed once in distilled water and observed through the transmission electron microscope, without contrasting the material, according to the method of Thiery ${ }^{[8]}$.

Detection of lipids: The mandibular glands were fixed in 2,5\% glutaraldehyde in $0.1 \mathrm{M}$ cacodylate buffer, $\mathrm{pH}$ 7.2 , for 2 hrs. The material was then washed once in the same buffer and once in $0.1 \mathrm{M}$ imidazole buffer, $\mathrm{pH}$ 7.5 , for $10 \mathrm{~min}$ each. The material was post-fixed in $2 \%$ osmium tetroxide in $0.1 \mathrm{M}$ imidazole buffer, $\mathrm{pH}$ 7.5. Afterwards, the material underwent two more washes in buffer, followed by acetone dehydration and then included in Epon resin, according to the method of imidazole-buffered osmium tetroxide ${ }^{[9]}$.

The ultrathin sections obtained were observed through the transmission electron microscope, without undergoing the contrast process.

\section{RESULTS AND DISCUSSION}

In order to obtain a better understanding and visualization, the results were arranged into Table 1 that shows the cytochemical site of the proteins, lipids and polysaccharides in the cells of all regions of the gland, including the secretions present in the lumen of the ducts, as well as inside the reservoir (Fig. 1-3 and Table 1).

The proteins are found to be like granules strongly electrondense in all the regions of the cells and in all analysed castes (Fig. 1 and Table 1), except inside the extracellular canaliculi of the media (Fig. 1L) and minima (Fig. 1M) workers and in the secretions that is in contact with the epithelium that overlays the reservoir of the minima workers (Fig. 1Q). However, high density is observed in the secretion that is in the region of the reservoir near to the secretory portion (Fig. 1P).

The lipids are present in all the analysed castes cells located in the cytoplasm of the secretory portion of the mandibular glands as electrondense droplets with an irregular border (Fig. 1 and Table 1). It is interesting to highlight that the lipids from the secretory cells have a double origin, i.e., they are formed in the smooth endoplasmic reticulum cisterns (Fig. 2B, C, H, D, I) as well in the mitochondria, since the latter frequently show disorganized cristaes and lipid droplets in its interior (Fig. 2A, E, F, G, L). Meanwhile, the presence of the lipids in the intra-and extracellular regions of the collector canaliculi and in the stored secretions inside the reservoir, was not detected (Fig. 2M, N, O, P, Q, R, $\mathrm{S}, \mathrm{T}, \mathrm{U})$.

The carbohydrates as well the proteins and lipids are distributed all over the glands of three castes as dispersed granules (Table 1). The cells of the secretory portion in all castes show high density in the test (Fig. 3 ), but on the collector canaliculi the carbohydrates are located only in the lumen of the intracellular canaliculi of the minima workers glands (Fig. 3M) and are absent in the same region of the other two castes (Figs. 3J, L). In the extracellular canaliculi of all castes, high density in the carbohydrates is detected (Fig. $3 \mathrm{~N}, \mathrm{O}, \mathrm{P}$ ). Inside the reservoir of the glands of the individuals of three castes, the secretion did not react to the test (Fig. 3R, S, T).

The relevance of the study of the mandibular glands of ants has been emphasized due to the fact that its products are of great importance to the processes of social regulation of the colonies, as well as interferes in the tasks performed by the individuals of the different castes.

Previous histochemical studies for the detection of lipids performed on the mandibular glands of the three worker castes of Atta sexdens rubropilosa ${ }^{[6]}$, showed the presence of lipids, mainly at the secretory portion of the glands. 
Table 1: Ultrastructural cytochemistry of proteins, lipids, and carbohydrates in the mandibular glands of the three worker castes of the ant Atta sexdens rubropilosa.

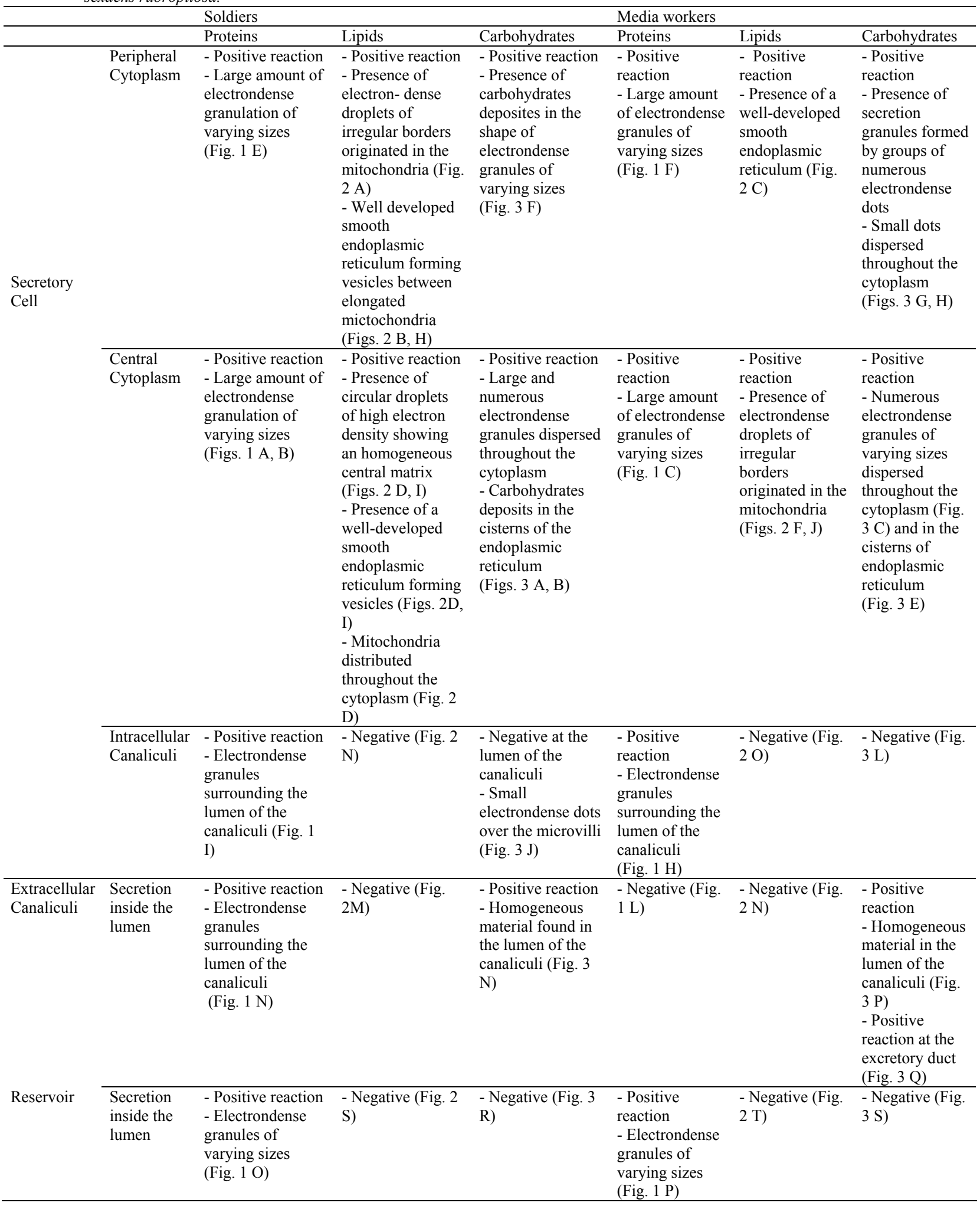


Table 1: Contd.

\begin{tabular}{|c|c|c|c|c|}
\hline & & \multicolumn{3}{|l|}{ Minina workers } \\
\hline & & Proteins & Lipids & Carbohydrates \\
\hline & Peripheral Cytoplasm & $\begin{array}{l}\text { - Positive reaction } \\
\text { - Large amount of } \\
\text { electrondense granules of } \\
\text { varying sizes (Fig. 1 G) }\end{array}$ & $\begin{array}{l}\text { - Positive reaction } \\
\text { - Presence of } \\
\text { electrondense droplets } \\
\text { originated in the } \\
\text { mitochondria (Fig. } 2 \text { E) }\end{array}$ & $\begin{array}{l}\text { - Positive reaction } \\
\text { - Presence of } \\
\text { carbohydrate deposits in } \\
\text { the shape of } \\
\text { electrondense dots of } \\
\text { varying sizes (Fig. } 3 \text { I) }\end{array}$ \\
\hline \multirow[t]{2}{*}{ Secretory Cell } & Central Cytoplasm & $\begin{array}{l}\text { - Positive reaction } \\
\text { - Large amount of } \\
\text { electrondense granulation } \\
\text { of varying sizes (Fig. 1 } \\
\text { D) }\end{array}$ & $\begin{array}{l}\text { - Positive reaction } \\
\text { - Presence of } \\
\text { electrondense droplets of } \\
\text { irregular borders } \\
\text { originated from the } \\
\text { mitochondria, which are } \\
\text { present in great numbers } \\
\text { (Figs. } 2 \mathrm{G}, \mathrm{L} \text { ) }\end{array}$ & $\begin{array}{l}\text { - Positive reaction } \\
\text { - Numerous } \\
\text { electrondense granules of } \\
\text { varying sizes dispersed } \\
\text { throughout the cytoplasm } \\
\text { (Fig. } 3 \text { D) }\end{array}$ \\
\hline & Intracellular Canaliculi & $\begin{array}{l}\text { - Positive reaction } \\
\text { - Electrondense granules } \\
\text { surrounding the lumen of } \\
\text { the canaliculi (Fig. } 1 \mathrm{~J} \text { ) }\end{array}$ & - Negative (Fig. 2 P) & $\begin{array}{l}\text { - Positive reaction } \\
\text { - Electrondense granules } \\
\text { over the microvilli (Fig. } 3 \\
\text { M) }\end{array}$ \\
\hline Extracellular Canaliculi & Secretion inside the lumen & - Negative (Fig. $1 \mathrm{M}$ ) & - Negative (Fig. 2Q) & $\begin{array}{l}\text { - Positive reaction } \\
\text { - Homogeneous material } \\
\text { in the lumen of the } \\
\text { canaliculi (Fig. } 3 \mathrm{O} \text { ) }\end{array}$ \\
\hline Reservoir & Secretion inside the lumen & $\begin{array}{l}\text { - Negative reaction for } \\
\text { the secretion found next } \\
\text { to the epithelium of the } \\
\text { reservoir (Fig. 1 Q) } \\
\text { - Strong positive reaction } \\
\text { for the secretion located } \\
\text { next to the cells of the } \\
\text { secretory portion (Fig. } 1 \\
\text { G) }\end{array}$ & - Negative (Fig. 2 U) & - Negative (Fig. 3 T) \\
\hline
\end{tabular}

These results were confirmed by the ultrastructural cytochemical analysis obtained in this work, with lipids being found in the form of droplets in the cytoplasm of the secretory cells.

These lipid droplets showed different morphologies and locations, such as next to cisterns of smooth endoplasmic reticulum and inside mitochondria, with these organelles being widely distributed throughout the cytoplasm of the secretory cells. The observation of lipids associated to the mitochondria of the mandibular gland had already been reported by ${ }^{[4]}$ when these glands were analyzed at the ultrastructural level in the individuals of this species of ants.

Researches studied the ovaries of workers and queens of the ant Neoponera villosa ${ }^{[10]}$ and reported that this type of association was frequent in these organs and suggested that in the ovaries of these individuals, the lipids found in the yolk would also originate in the mitochondria. Caetano ${ }^{[11]}$ analyzed the post-pharyngeal glands of Dinoponera australis and reported some modifications of the mitochondria, thus attributing to these organelles the function of lipid production and denominating them as derived mitochondria. Abdalla ${ }^{[12]}$ also evidenced mitochondria storing lipid materials in their inside when analyzing the ultrastructure of the Dufour gland of Scaptotrigona postica.
Therefore, the data of the present study show that the lipids present in the mandibular gland of the three worker castes of the ant A. s. rubropilosa would have at least two different sources: the smooth endoplasmic reticulum and the mitochondria of the secretory cells.

With the exception of the secretory cells of the mandibular glands of the individuals of the three worker castes of A. s. rubropilosa, lipids were not found at any other region of the mandibular glands analyzed, at least not in amounts significant enough to be detected. The regions lacking lipids were the lumen of the intra and extra-cytoplasmic canaliculi and the secretion stored inside the reservoir.

Previous histochemical studies performed on the mandibular glands of the species in question Pavon ${ }^{[6]}$ also revealed the presence of carbohydrates in these organs; these results were also confirmed through the ultrastuctural cytochemical analysis presented here. Carbohydrates were detected in the shape of an electrondense granulation at the secretory portion of the mandibular glands in the three castes studied. However, we did not detect carbohydrates in the lumen of the intracellular canaliculi, of either soldiers or media workers, nor in the secretion stored in the reservoir of the three worker castes.

The fact of having observed the presence of carbohydrate deposits at the cisterns of endoplasmic reticulum of the secretory cells of the mandibular glands of soldiers and media workers of 


\section{Figura 1}
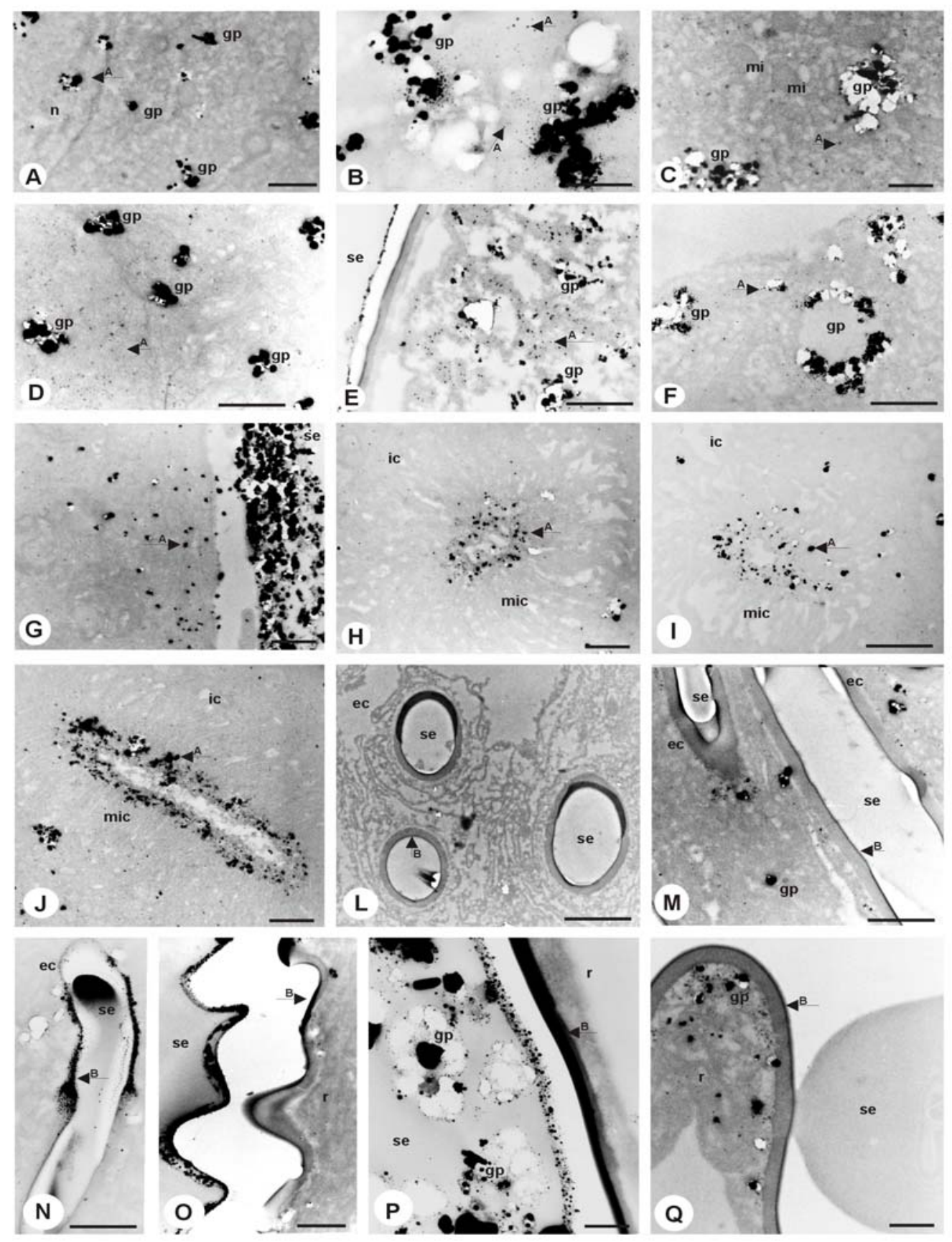

Fig. 1: Detection of proteins in the mandibular glands of worker ants of Atta sexens rubropilosa. A, B, C, D) Secretory portion: central cytoplasm. A) Soldier-Scale bar: $1 \mu \mathrm{m}$; B) Soldier-Scale bar: $1 \mu \mathrm{m}$; C) Medium worker-Scale bar: 0,5 $\mu \mathrm{m}$; D) Minima worker-Scale bar: 0,5 $\mu \mathrm{m}$; E, F, G) Secretory portion: peripheral cytoplasm. E) Soldier-Scale bar: $1 \mu \mathrm{m}$; F) Medium worker-Scale bar: $1 \mu \mathrm{m}$; G) Minima worker-Scale bar: $0,5 \mu \mathrm{m} ; \mathrm{H}, \mathrm{I}, \mathrm{J})$ Secretory portion: Intracytoplasmic canaliculi. H) Medium worker-Scale bar: $0,5 \mu \mathrm{m}$; I) Soldier-Scale bar: $1 \mu \mathrm{m}$; J) Minima worker-Scale bar: 0,5 $\mu \mathrm{m} ; \mathrm{L}, \mathrm{M}, \mathrm{N})$ Extracytoplasmic canaliculi. L) Medium worker-Scale bar: $2 \mu \mathrm{m}$; M) Minima worker-Scale bar: $1 \mu \mathrm{m}$; N) Soldier-Scale bar: 0,5 $\mu \mathrm{m} ; \mathrm{O}, \mathrm{P}$, Q) Reservoir. O) Soldier-Scale bar: $1 \mu \mathrm{m}$; P) Medium worker-Scale bar: 0,5 $\mu \mathrm{m}$; Q) Minima worker-Scale bar: $0,5 \mu \mathrm{m}$. n: nucleus; gp: protein granules; arrow A: protein granules; mi: mitochondria; se: secretion, ic: intracytoplasmic canaliculi; mic: microvilli; ec: extracytoplasmic canaliculi; arrow B: cuticle; r: reservoir. 


\section{Figura 2}
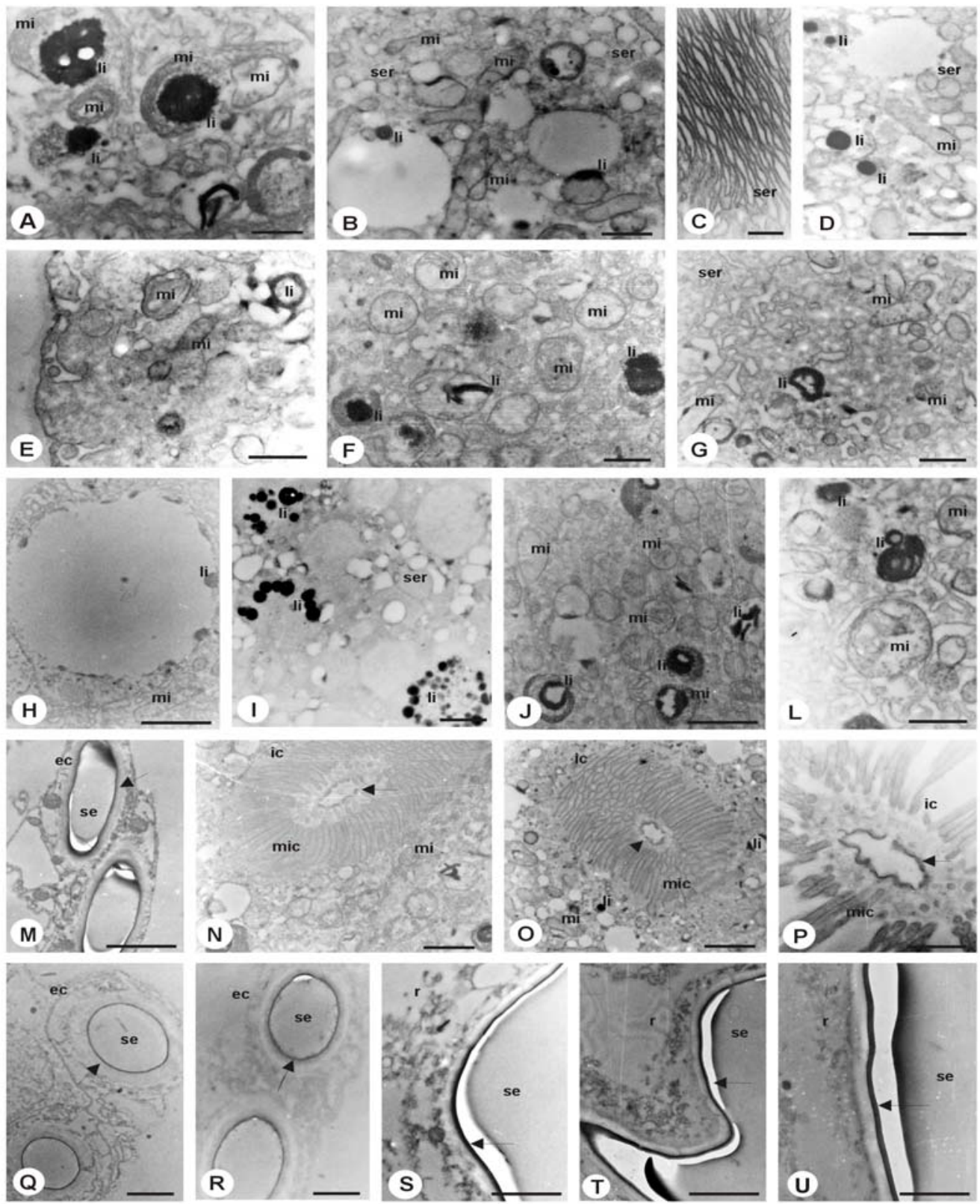

Fig. 2: Detection of lipids in the mandibular glands of worker ants of Atta sexdens rubropilosa. A, B, C, E) Secretory portion: peripheral cytoplasm. A, B) Soldier-Scale bar: $1 \mu \mathrm{m}$; C) Medium worker-Scale bar: 0,25 $\mu \mathrm{m}$; E) Minima worker-Scale bar: $1 \mu \mathrm{m} ; \mathrm{D}, \mathrm{F}, \mathrm{G})$ Secretory portion: Central cytoplasm. D) Soldier: $1 \mu \mathrm{m}$. F) Medium worker-Scale bar: 0,5 $\mu \mathrm{m}$; G) Minima worker-Scale bar: $2 \mu \mathrm{m} ; \mathrm{H}, \mathrm{I}, \mathrm{J}, \mathrm{L}$ ) Lipid granules. H) Soldier-Scale bar: 0,5 $\mu \mathrm{m}$; I) Soldier-Scale bar: 0,5 $\mu \mathrm{m}$; J) Medium worker-Scale bar: $1 \mu \mathrm{m}$; L) Minima worker-Scale bar: $1 \mu \mathrm{m}$; N, O, P) Secretory portion: Intracytoplasmic canaliculi. N) Soldier-Scale bar: 1 $\mu \mathrm{m}$; O) Medium worker-Scale bar: $1 \mu \mathrm{m}$; P) Minima worker-Scale bar: $1 \mu \mathrm{m}$; M, Q, R) Extracytoplasmic canaliculi. M) Soldier-Scale bar: $1 \mu \mathrm{m}$; Q) Minima worker-Scale bar: 0,5 $\mu \mathrm{m}$; R) Medium worker-Scale bar: $0,5 \mu \mathrm{m} ; \mathrm{S}, \mathrm{T}, \mathrm{U})$ Reservoir. S) Soldier-Scale bar: $1 \mu \mathrm{m}$; T) Medium worker-Scale bar: $1 \mu \mathrm{m}$; U) Minima worker-Scale bar: $1 \mu \mathrm{m}$. li: lipids; mi: mitochondria; ser: smooth endoplasmic reticule; se: secretion; ec: extracytoplasmic canaliculi; arrow: cuticle; ic: Intracytoplasmic canaliculi; mic: microvilli; r: reservoir. 
Figura 3

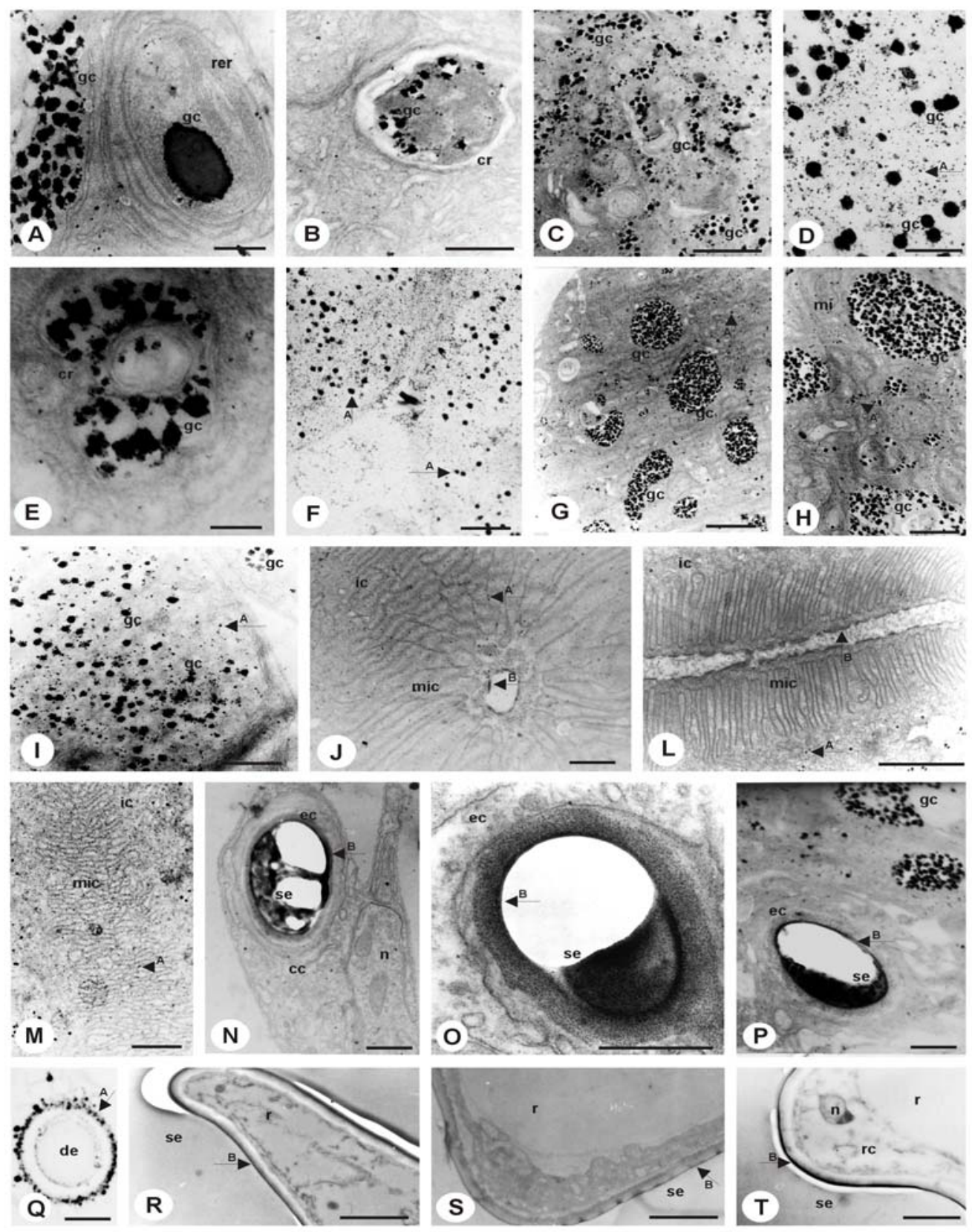

Fig. 3: Detection of carbohydrates in the mandibular glands of worker ants of Atta sexdens rubropilosa. A, B, C, D, E) Secretory portion: Central cytoplasm. A) Soldiers-Scale bar: $2 \mu \mathrm{m}$; B) Soldiers-Scale bar: 0,5 $\mu \mathrm{m}$; C) Medium workers-Scale bar: 0,5 $\mu \mathrm{m}$; D) Minima workers-Scale bar: 0,25 $\mu \mathrm{m}$; E) Medium workers-Scale bar: $2 \mu \mathrm{m}$; F, G, H, I) Secretory portion: peripheral cytoplasm. F) Soldiers-Scale bar: $1 \mu \mathrm{m}$; G) Medium workers-Scale bar: $1 \mu \mathrm{m}$; H) Medium workers-Scale bar: 0,5 $\mu \mathrm{m}$; I) Minima workers-Scale bar: $1 \mu \mathrm{m}$; J, L, M) Secretory portion: intracytoplasmic canaliculi. J) Soldiers-Scale bar: 0,5 $\mu \mathrm{m}$; L) Medium workers-Scale bar: $0,5 \mu \mathrm{m}$; M) Minima workers-Scale bar: $1 \mu \mathrm{m}$; N, O, P) Extracytoplasmic canaliculi. N) Soldiers-Scale bar: 0,5 $\mu \mathrm{m}$; O) Minima workers-Scale bar: 0,25 $\mu \mathrm{m}$; P) Medium workers-Scale bar: 0,5 $\mu \mathrm{m}$; Q) Medium workers-Scale bar: $0,5 \mu \mathrm{m}$; R, S, T) Reservoir. R) Soldiers-Scale bar: $1 \mu \mathrm{m} ; \mathrm{S}$ ) Medium workers-Scale bar: $1 \mu \mathrm{m}$; T) Minima workers-Scale bar: $1 \mu \mathrm{m}$. gc: carbohydrate granules; rer: rough endoplasmic reticule; cr: reticule cistern; arrow A: carbohydrate granules; mi: mitochondria; ic: intracytoplasmic canaliculi; mic: microvilli; arrow B: cuticle; ec: extracytoplasmic canaliculi; se: secretion; cc: canaliculi cell, n: nucleus; de: excretory duct; r: reservoir; rc: reservoir cell. 
A. s. rubropilosa could indicate that the addition of sugars to other type of macromolecules, such as proteins and/or lipids, could be occurring in this organelle.

Pavon $^{[6]}$ studied the histochemical properties of the mandibular glands of the individuals of the three worker castes of $A$. s. rubropilosa and also evidenced the presence of proteins in the cells of the secretory portion of the mandibular glands. This result was confirmed by the ultrastructural cytochemical analyses, which revealed the presence of proteins in the shape of an electron dense granulation of varying sizes depending on the region of the gland under consideration: secretory cells, intra-and extracellular canaliculi, or reservoir. Specifically in the minima and media workers, the extracytoplasmic canaliculi failed to react consistently to this test. Nevertheless, the secretion stored inside the reservoir always showed a positive reaction to the test for proteins.

In the same work, Pavon ${ }^{[6]}$ analyzed the protein profile of the mandibular glands of the individuals of the three worker castes of $A$. s. rubropilosa through the evaluation of total protein content and denaturing gel electrophoresis. These authors showed that the total protein content, as well as the number of polypeptides, present in the mandibular glands of the different castes obeys a progressive order relating the size of the individuals to the tasks they perform inside the colony. Therefore, the soldiers, who perform tasks outside the nest such as foraging and excavation, but also aid in the communication and defense of the colony, presented the highest amount of different proteic elements in the secretion found in the reservoir of the mandibular glands of this ant species. The media workers, which have been classified as generalist given that they perform tasks inside the nest but also cut, transport and maintain viable the fungal cultures, presented a slightly lower protein content but higher than that of the minima workers, the latter known as gardeners because they perform tasks related to the culture of the fungus inside the nest and also aid in brood care.

The results of the present study suggesting that the final product secreted by the mandibular glands of the individuals of the three worker castes of $A . s$. rubropilosa is composed by lipids, carbohydrates and proteins, the latter probably in the form of enzymes that may be involved in bactericidal and/or fungicidal functions. These results thus corroborate previous studies of other ants glands like the metapleural ones of other ants of the Attini tribe showing the participation of proteins in the final secretion of this gland ${ }^{[13]}$, which would be involved in the production of substances related to maintaining the antiseptic condition of the colony, as well as in the production of substances that would aid the fungal growth ${ }^{[14]}$.

The present study has shown that the mandibular glands of the individuals of the three worker castes of
A. S. rubropilosa mainly the soldiers and media workers, who are individuals that perform tasks outside the nests and are thus more exposed to predation and/or infection and also the minima workers, who take care of the fungal culture, produce compounds that could play roles in alarm and/or defense. Moreover, it is possible that the mixture of these compounds would be important in order to perform the different tasks efficiently, thus rendering the information more precise by means of coordinated chain reactions.

\section{ACKNOWLEDGEMENTS}

This work was supported by the Brazilian research agency FAPESP (Fundação de Amparo à Pesquisa do Estado de São Paulo), Grant No. 03/00553-8. We are grateful to Antonio T. Yabuki, Monika Iamonte for the technical support.

\section{REFERENCES}

1. Wilson, E.O., 1971. The Insect Societies. The Belknap Press. Harvard Univ., pp: 548.

2. Cruz-Landim, C., 1967. Estudo comparativo de algumas glândulas das abelhas (Hymenoptera, Apoidea) e respectivas implicações evolutivas. Arq. Zool., 15: 177-290.

3. Nedel, J.O., 1960. Morphologie und Physiologie der mandibeldruse einiger Bienen-Arten (Apidae). Zeitschrift fur Morphologies und Okologie der Tiere, 49: 139-183.

4. Pavon, L.F. and M.I. Camargo-Mathias, 2005. Ultrastructural studies of the mandibular glands of the minima, media and soldier ants of Atta sexdens rubropilosa (Forel 1908) (Hymenoptera: Formicidae). Micron., 36: 449-460.

5. Costa-Leonardo, A.M. and C. Cruz-Landim, 1985. Aspectos ultra-estruturais das glândulas mandibulares de rainhas de Apis mellifera L. (Hymenoptera: Apidae). Rev. Brasil. Biol., 45: 2131.

6. Pavon, L.F. and M.I. Camargo-Mathias, 2004. Histochemistry and protein profile of the mandibular glands of workers of the ant Atta sexdens rubropilosa (Hymenoptera: Formicidae). Cytologia, 69: 225-234.

7. Macrae, E.K. and G.D. Meetz, 1970. Electron microscopy of ammoniacal silver reaction for histones in erythropoietic cells of chick. J. Cell Biol. New York, 45: 235-245.

8. Thiery, J.P., 1967. Mise em evidence des polysaccharides sur coupes fines en microscopie electronique. J. Microscopic., 6: 987-1018.

9. Angermüller, S. and D.H. Fahimi, 1982. Imidazole-buffered osmium tetroxide: An excellent stain for visualization of lipids in transmission electron microscopy. Histochem. J., 14: 823-825. 
10. Caperucci, D. and M.I. Camargo-Mathias, M.I. 2006. Lipids in oocytes of Neoponera villosa ants (Hymenoptera: Ponerinae). Sociobiology, 47: 531542.

11. Caetano, F.H., F.J. Zara and E.A. Gregório, 2002a. The origin of lipid droplets in the post-pharyngeal gland of Dinoponera australis (Formicidae: Ponerinae). Cytologia, 67: 301-308.

12. Abdalla, F.C. and C. Cruz-Landim, 2005. Ocorrência, morfologia e ultra-estrutura da glândula de Dufour de Scaptotrigona postica Latreille (Hymenoptera, Meliponini). Neotrop. Entomol., 34: 47-57.
13. Do Nascimento, R.R., E. Schoeters, E.D. Morgan, J. Billen and D.J. Stradling, 1996. Chemistry of metapleural gland secretions of three attine ants, Atta sexdens rubropilosa, Atta cephalotes and Acromyrmex octospinosus (Hymenoptera: Formicidae). J. Chem. Ecol., 22: 987-1000.

14. Caetano, F.H.., K. Jaffé and F.J. Zara, 2002b. Formigas: Biologia e Anatomia. Ed. Topázio. Araras, S.P., pp: 131. 